\title{
Physics caught in fight over future plans for US energy department
}

Washington. A panel of newly elected Republicans in the US House of Representatives has set out plans to disband the Department of Energy (DoE). It proposes appointing a 'closure commission' to rationalize the department's world-renowned network of physics laboratories, and transferring responsibility for nuclear weapons research and development to the Pentagon.

This drastic proposal marks the starting point of a high-stakes game of power politics in Washington, the outcome of which will reshape support for the physical sciences in the United States. Last year, the Department of Energy spent $\$ 6.5$ billion on research and development, most of it on nuclear weapons, energy supply, and highenergy and nuclear physics.

There are three possible futures in sight for DoE: disbandment, as proposed by the House panel; the absorption of its research activities into a new Department of Science, as championed by Bob Walker (Republican, Pennsylvania), chair of the House Science Committee; or its retention on a considerably reduced scale, as advocated by the Clinton administration and the energy secretary, Hazel O'Leary.

Disbandment was endorsed at a press conference last week by Bob Dole (Republican, Kansas), majority leader in the Senate and presidential candidate, Dick Armey (Republican, Texas), majority leader in the House, and John Kasich (Republican, Ohio), chairman of the House Budget Committee.

This proposal would place the three weapons laboratories - Los Alamos, Sandia and Lawrence Livermore - in a new, civilian, Defense Nuclear Programs Agency inside the Department of Defense (DoD), along with the DoE's vast nuclear clean-up programme.

The rest of the DoE's 30 or so laboratories would be handed over to an Energy Laboratory Facilities Commission. This would recommend a programme of laboratory closures and consolidations which Congress would have to accept in one package, to avoid endless political wrangling.

"There are far too many laboratories, and far too much 'pork'," said Kasich. "We badly need a laboratory closure commission." Defending the plans to bring nuclear weapons research into DoD, Todd Tiahrt (Republican, Kansas), chair of the freshmen's panel, said that the Manhattan Project to build the atomic bomb had

\section{MIT nuclear laboratory feels chill wind}

Boston. Shock-waves passed through the Massachusetts Institute of Technology (MIT) last week when it was informed that a congressional subcommittee was planning to cut off funds for the university's Bates Linear Accelerator.

Two days later, the House of Representatives' energy and environment subcommittee voted on a proposal to restore the facility's \$18.6-million budget. But the amendment was defeated in a 12-12 tie.

Four other university-run accelerators - at Yale, Texas A\&M, the University of Washington, and the Triangle Universities Nuclear Laboratory in North Carolina also face closure as a result of proposed Department of Energy (DoE) budget cuts totalling \$31 million (see above).

The subcommittee plan still has a long way to go in Congress before the fate of any of these facilities is sealed. But MIT physicists have still been stunned by the recommendation. According to Robert Redwine, director of the MIT Laboratory for Nuclear Science, a recent interim report from the federal Nuclear Science Advisory Committee (NSAC) underscored the critical importance to the nation of maintaining small university accelerators.

The Bates accelerator was specifically cited for its contribution to US nuclear physics. "The NSAC worked hard to develop a long-range research strategy that was optimal for the nation," Redwine added. "There is no indication that the House subcommittee members paid much attention to this review."

MIT would be hit particularly hard by the House subcommittee plan. The money it receives from DoE supports 22 graduate students, 6 faculty members, and $\mathbf{3 0}$ graduate students from other universities, as well as an operating staff of 122. The facility is used by 250 scientists from 50 institutions around the world. "Educational value alone is not enough to keep facilities going," says Redwine.

Stanley Kowalski, the director of Bates, admits that he and his colleagues need to do more to explain the attributes of their nuclear physics facilities. "Most Congressmen are not scientists, and we'd like to educate them," he said. "We want them to take a careful look at what they're proposing to see if it's really best for the country."

Steve Nadis

worked under military control.

Kasich warned the freshmen that "we're going to have to fight some of our own people to get this done," and the proposal is likely to meet significant opposition from senators with laboratories in their states, most notably Pete Domenici (Republican, New Mexico), chair of the Senate Budget Committee.

While some continue to make the administrative and ethical case for civilian control of nuclear weapons research, Domenici

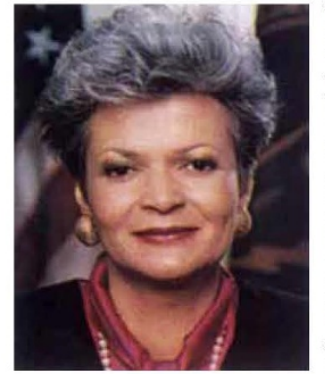

o'Leary: faces gulf with laboratories. will be more concerned about the prospective abilities of Los Alamos and Sandia to retain their budgets inside $\mathrm{DoD}$, at a time when there are no plans for new nuclear weapons. At the same time, environmentalists may react strongly to the idea that nuclear clean-up should come within the secretive web of the Pentagon.

Thus, despite its heavyweight backing, the freshmen's proposal raises obvious problems, as anticipated by Walker's proposal for a Department of Science (see Nature 374, $201 ; 1995)$. Having failed to incorporate the proposal in the House Republican budget, Walker is not discouraged: "As we go further down the road [of determining the DoE's future] the concept of a Department of Science will come to the fore," he predicts.

Plans for such a department - which would also incorporate the National Science Foundation, the National Aeronautics and Space Administration (NASA) and several other science agencies - have been criticized by Jack Gibbons, President Clinton's science adviser, and others on the grounds that they would separate science at DoE and NASA from the missions that they are supposed to support.

In response, supporters claim money for science would be safer if it were clearly labelled as such by being placed inside a Department of Science. Even in this Congress, no-one ever has a bad word for science - but it is still cut, the argument goes, because it rests inside unpopular agencies.

The Department of Science solution is certainly more elegant than its critics often admit, but it lacks political support outside the office of the man who would oversee the new department, namely Walker himself.

That leaves a slimmed-down Department of Energy as the most probable alterna- 
tive to the disbandment proposal. The department is likely to be cut back considerably more than Secretary O'Leary would like; last week, the House energy and environment subcommittee, chaired by Dana Rohrabacher, passed an authorization bill that would cut DoE's civilian research and development activities next year by a quarter, from $\$ 5.3$ billion to under $\$ 4$ billion.

DoE laboratory directors are now working fervently with O'Leary to improve their relations with the department along the lines of proposals contained in one part, Appendix B, of the report by the industrialist Robert Galvin into their future (see Nature 373, 463; 1995) - the second-best option, according to Galvin. Without such a course of action, observes one laboratory director, reform of the laboratories becomes "a wide open ball game for the crazies".

But the effectiveness of reform will be hindered by the gulf between O'Leary and the laboratories, where she is admired and despised in almost equal measure. While many DoE scientists complain of her poor attention to detail and lack of commitment to sacred nostrums, her political and presentational skills have improved the department's once-wretched public image.

Indeed, a poll published in the Wall Street Journal last week found that the public opposed abolition of DoE by 63 to 25 per cent. Nevertheless, the department's fate will be decided not by the public, but by the Senate - the fulcrum of power on many issues between an angry House and a complacent administration.

Meanwhile, the Rohrabacher bill set out a worst-case scenario for the DoE's 1996 budget, which will be finalized between now and September. The bill would slash funding for solar and renewable energy research from $\$ 420$ million to $\$ 200$ million; nuclear energy research from $\$ 190$ to $\$ 120$ million and fusion research from $\$ 370$ million to $\$ 230$ million.

It would, however, seek to protect basic science by raising support slightly for basic energy sciences and high-energy physics. "If you're a wolf caught in a trap and you need to cut a leg off to escape, best make sure it's the right leg," asserts Rohrabacher, a fiery conservative who clearly enjoyed seeing off attempts to soften his spending cuts.

The House Science Committee is passing unusually detailed authorization bills this year. This is an attempt to reassert its influence on the appropriations subcommittees, which have the last word on budgets. The attempt has the backing of the House leadership and the appropriations bills are likely to contain broadly similar numbers.

The Rohrabacher bill would also eliminate seed funding of $\$ 6$ million for US participation in Europe's Large Hadron Collider (LHC) project. But Walker says he and John Myers (Republican, Indiana), chairman of the energy appropriations subcommittee, both support the LHC and will seek to restore this money.

Colin Macilwain

\section{Tax problems threaten cuts in young scientist grants}

Munich. The European Commission may have to reduce by 500 the number of fellowships it can offer to young scientists intending to study in another European Union (EU) state. The commission told the council of research ministers in Luxembourg last week that it may have to extend a decision taken last December - to reimburse those holding fellowships under its new Training and Mobility of Researchers (TRM) programme who have to pay tax - to the entire duration of the four-year programme.

The problem has arisen because some member states do not exempt EU research grants from tax and social security deductions. But the compensation will come out of the commission's research funds, and its extension would, therefore, mean a 10 per cent reduction in the number of fellowships that can be offered.

The TRM programme is part of the EU fourth Framework programme, and will provide ECU260 million (US\$343 million) in fellowships to young scientists wishing to work for up to two years in another member state between 1995 and 1998 .

It follows the previous Human Capital and Mobility programme, which ran into

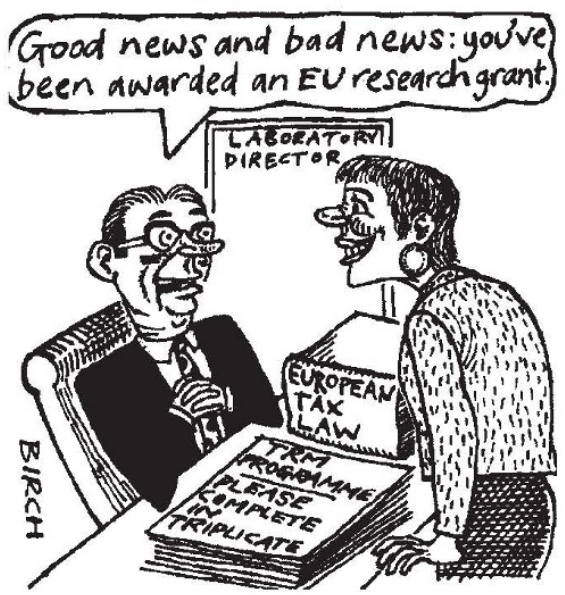

difficulties because it offered a single rate for grants regardless of the host country's tax and social security rules. As a consequence, young scientists working in countries such as France, where they were required to pay such taxes, found themselves in financial difficulties, while those working in countries such as the United Kingdom or Italy sometimes ended up with higher pay than their departmental heads.

Further complications arose because bursaries were not accompanied by bench fees, while no allowances were made for differing overhead requirements between host institutes, or for fluctuating exchange rates. As a result, the commission came in for some harsh criticism for not having predicted the difficulties in administering its grants fairly (see Nature 361, 196; 1993).

In response, the commission set up a committee last year to establish a payment system tailored to national pay scales, as well as the tax and social security conditions in individual member states. Delegates from each state have proposed figures that would allow grant recipients to receive take-home pay equivalent to that of local scientists.

These figures, which have been informally approved by member states, will be used when the first TRM grants from the programme are paid in October. In addition to the basic pay, the commission will provide an additional sum of about ECU200 a month to compensate for the inconvenience of living abroad, and around ECU10,000 a year to the host institute for bench fees.

When the new programme was put before research ministers for their approval in December, it was agreed that, in order to avoid a delay in its launch, the commission should cover the cost of taxes for the first year of the programme. The council also asked the commission to set up a committee of taxation experts to recommend a longerterm solution.

Presenting its conclusions to the council of research ministers last week, the taxation committee proposed that the system of individual compensation be continued until the end of the current programme, as it saw no short-term prospect of persuading all member states to harmonize their tax laws on this issue. But it suggested that the commission should work towards ensuring harmonization by the beginning of the fifth Framework programme in 1999.

The solution - which is likely to be approved by the council of research ministers - saves the commission from further embarrassment on the issues. But because the compensation money must be found from its own resources, the commission estimates that it will be able to offer 10 per cent fewer fellowships.

Although many scientists will benefit from the new scheme, it may take time to win the confidence of those who find $\mathrm{EU}$ programmes more trouble than they are worth. David Colquhoun, for example, professor of pharmacology at University College London, applauds the goal of promoting mobility of scientists within Europe. But he adds: "the bureaucracy involved [getting EU grants] is widely laughed at. It's ten times as much work to get funds from the EU as from national sources."

Despite such reservations, the previous Human Capital and Mobility programme attracted nearly 12,000 applications, 30 per cent of which were funded. Alison Abbott 
